\title{
The BRICS: Paradigm Shift in Dealing with New Challenges
}

\author{
Essay \\ B.F. Martynov \\ MGIMO University, Moscow, Russian Federation
}

\begin{abstract}
The mankind has been actively using a relatively new geopolitical space: the space of information. Obviously, the economic and scientific progress opens new horizons and possibilities, still not clearly understood by people. This brings about many changes, with either good or bad consequences, depending on who uses the information and what aims are pursued. The present system of international relations is characterized by many new features; it's becoming more "unpredictable" and "chaotic". Information wars and "fake" news contribute in its turn to the turbulent character of international relations, pushing forward misconceptions and distorted visions of different situations, and thus provoking conflicts. At the same time, the world is badly short of new ideas, which could more adequately answer the global problems. These new ideas could hardly be produced by the "old", traditional actors. At the same time, the BRICS countries, representing the new "ascending" civilizations of non-Western nature and not being bound in this sense by the rules of "Euro-Atlantic solidarity", could collectively propose some new approaches to the global issues. BRICS, as a format of states with accelerated economic indices, should lay a wider conceptual platform for its further dynamics. It should provide a more active information policy and elaborate a "new" conceptual basis, founded on rather traditional and "old" principles - common respect for the international law, derived from political and juridical cultures, historic and social practices.
\end{abstract}

Key words: geopolitics, global problems, global security, informatics space, information security, BRICS, world civilizations, "multi-civilizational" approach, international law, political and juridical cultures

The politics of war and peace have been traditionally constructed around material spaces, which, insofar, acquired political dimensions. Initially, there have been two: ground and sea surfaces. The 20th century added to them a new one - an air space, and by the end of it - the cosmic space. This process of multiplication of those physical and politically competitive spaces was maintained by the technical / scientific development, constantly pushed forward by wars and military build-ups. The 21 st century added a differently new, virtual kind of space an "informatic", or a "cyberspace".

Main security actors and their interests have been closely linked with all these spaces. "Classic" state security interests depended on land, sea and air premises. They provided for military security and for the military strength to maintain and/or to conquer those territorial or sea spaces. The emergence of transnational corporations accentuated the parameters of economic security and economic strength, with stronger accent on natural resources. Materialistic and space-centered approaches produced the two World Wars, but after the last WW, a special focus was made on the so-called indirect instruments of domination - economic, informative and moral (human rights). The present day international policy has become, at least, partly virtual, a new principal actor of it being a human person - an elector.

A "true believer" is always better than a "strong defender". When information penetrates the minds, neither states, nor transnationals need a "classic" war to achieve their goals. "Soft" (or "smart") power works better: one, who governs human conscience, may govern the world. The political actors (including international bodies), who can rapidly produce and make proper use of information, are in better conditions than those, who cannot. In the "hybrid war" realities, information, no difference true or false, is of a special demand for all international actors. Stakes are quite high: the future of the world, nowadays is torn up between global problems and subjective ambitions. The statement of President V. Putin: "Those, who govern the IT-technologies, will govern the world", perfectly reflects the today's reality.

BRICS (Brazil, Russia, India, China and South Africa) appeared in 2006 as an innovative structure of non-Western nature. Initially it was launched as a format of states with accelerated economic indices, but nowadays its raison d'étre can no longer be seen exclusively through the prism of economy. Other- 
ways, BRICS will become just one of so many already existing international structures. Obviously, without its own ideas on a wide range of modern political, economic, social and philosophical issues this unprecedented project will inevitably lose its proper "face" and identity. As a conglomerate of the most important world civilizations of non-Western nature, BRICS can organize and maintain a long standing dialogue for the new conceptualization of global agenda in a form of a multi-civilizational and multi-cultural world order.

When some scholars predict the "end" of the BRICS project because of its current economic, cultural, political etc. differences, from the point of view, centered, as earlier, around the "material" and "physical" spaces, they, after all, might be right. In a full "normativistic" state of affairs there should have been the BRICS failure long ago. According to some authors, preoccupied with the maintenance of the status quo, the 21 st century will do quite well without the "ascending" countries, with the "good old" global leaders still governing the world [Sharma 2010]. But, as others [Toropchin 2017] say, the BRICS has already ceased to be a purely economic project. The current world realities have been constantly pushing the focus of its interests from economy to security and "high" global politics. It means, that the BRICS leaders follow the main global trends, giving credit to the problems other, than purely economic ones [Martynov, Lavalle 2019]. It is confirmed by the fact of constant expansion of its interests to other spheres (social, cultural, etc). Besides, in spite of its current economic differences, which are by definition changing, the world public opinion still gives credit to this unprecedented inter-civilizational format.

The new, "multi-civilizational" format, little by little gains space and authority in the world and receives a broad "coverage" in the international academic community. Small wonder that it meets with the "covert" opposition from the "mono-civilizational" party. The "post-huntingtonians" in the United States try to revise S. Huntington, proposing a certain "Civilization of Modernity". On their opinion, it will consist of "independent", "equal" and "free" civilizations (European, Chinese, Japanese, Hindu, and "Afro-Eurasian") with one (the "Anglo-American") "more equal, than others" to "supervise" them [Katzenstein 2010-2012]. Even more sophisticated in this respect looks an approach presented by Ian Morris in his book "War: What is it Good for?" that illustrates the "poverty" of ideas, so characteristic for the "old", traditional actors of the world politics. The "non-conformist" author not only praises wars of the past that have, allegedly, made us "safer and wealthier" (?!). He eventually welcomes a new one, the 3rd WW, to take place, first, in the cyber-space and, than, in the "traditional" spaces: land, sea and air. The final victory in the coming war will belong to the most developed nation (no difficulty to guess which one), acting as a powerful electronic "globocop" against the "criminal will" and deeds of the "under-developed" nations. On his opinion, "If the United States fails, all the world fails" [Morris 2014].

Almost the same ideas are reflected in the book with a pretentious name "Homo Deus" by the popular author Yuval Harari. As in the times of the old Soviet Union propaganda, the author promises to the mankind a Paradise on the Earth without wars, poverty and even death (!). This new society will be constructed on the strictly individualistic base and without those peoples, who will not (as the American Indians) absorb the imperatives of the new scientific and technical revolution and will ignore the demands of the information society [Harari 2015]. So, such and some other authors, belonging to the modern Western train of thought, give us a full right to say: "If the BRICS fails, all the world fails".

From this point of view it deems unnecessary to repeat in each and one declaration of the BRICS summits, that this format "it is not intended against anybody". It seems a donation to the very "political correctness", that is uncharacteristic, so far, for the whole BRICS mentality. As a potential counterweight to the omnipotent "Anglo-America" [Katzenstein 2010 - 2012], the BRICS format will never be welcomed by the West. A wholly skeptical (or, at the best, ignorable) attitude of the Western elites and media towards the BRICS and its perspectives must be taken for granted, though the BRICS leaders never lose a possibility to mention their openness for the cooperation with the "West" on practically all modern world problems: from climate changes to terrorism.

Once it was said: "Having in mind the traditional respect of the BRICS countries towards the international law, we could, for example, put this subject in the center of our discussions with the 
United States" [Voronin 2013]. But, can we, really? The Anglo-American Common law (precedent) system and its corresponding juridical culture differ from the majority of the BRICS legal systems [Martynov 2019]. So, our understanding of the international law is and will always be necessarily different. As different are our attitudes towards the majority of global problems: their origins, nature and, necessarily, the ways of their resolution. The best example in this sense might be the problem of international terrorism. While the BRICS countries are all for the elaboration of the legal definition of "terrorism" under the UN authority, the USA and their closest allies are strongly against. This fully enables them here and again to make the terrorists go for "freedom fighters" and vice versa in their narrow political interests.

"In the actual atomized societies the citizens and classes disappear as the agents of changes. Ours turns out to be the world of individualists who get united only as consumers of goods or information and trust more in Internet than in their representatives in parliaments. ... This individualistic world, moved by money, outshadows the more ancient vision of common values... The idea of world governance is turning to be a dream of the past" [Mazover 2017]. $\mathrm{H}$. Kissinger says that the very notion of "verity" is nowadays being relativized and individualized, while the "abundance of irrelative information makes the real knowledge disappear" [Kissinger 2014].

Individualism, as a strong Anglo-American credo, serves well for the economic development, but can hardly contribute to the resolution of the most of global problems, created by it. Because of their complex and common for all character. Besides, on our point of view, all the necessary innovations in ideological sphere, to be viable, can come only from those countries and civilizations, which stood for the most time of the human history apart from the "big" global politics and, as a result, have not been "overloaded" with the old patterns and schemes, set forth by the "great powers". On our point of view, to fruitfully contribute to the resolution of the present and future global problems one should have at least some general common approaches to them. In the world, where the authority of the international law is at its lowest, the imperatives of the BRICS countries cooperation and the importance of the BRICS + countries efforts in the correction of the present situation can't be overestimated. The main reason for that being their traditionally respectful attitude towards the international law, based on their close juridical grounds (Roman law).

Some authors, among them Jim O'Neil, the author of the "BRICS" acronym, say, that the process of globalization should not necessarily be limited to the paradigm of "Westernization" or "Americanization". The "club" of the "Western democracies", on his opinion, has, probably, "outlived" itself, and the "G-20" group becomes more legitimate, than the "G-7", on the mere fact, that it includes the BRICS countries [O'Neill 2011]. Other scholars also confirm, that the "economic reality" has proved to be more complex than we used to imagine earlier, because it depends on cultural, historic, religious, social, etc. backgrounds. For example, happiness, as a general notion, can't be measured by the GNP per capita: it has different meanings in different cultures and countries: it can't be imposed from above. "The real picture of the world has many pikes" - this can be the slogan of the BRICS countries.

But what of purely economic well-being, doesn't it have any significance more? On the first sight, the ultimate goal of the newly created BRICS Bank (2013) was quite traditional: "economic development". Nevertheless, time has come to ask: "What kind of "development"? Needs it follow the same patterns of degradation of nature, social polarization, poverty, epidemics, ethnic wars, tribal conflicts etc.? Not to find and to explain to others the proper BRICS-understanding of such notions, as "development", "progress", "well-being", "law", "world order", "democracy", etc., means to silently agree with the traditional understandings, leaving things as they are. Doing this means to capitulate before the coming global collapse [Diamond 2011].

There are other innumerous imperatives. Let's take one for example: struggle against heightened criminal activity and criminal bands, which flourishes in spite of all benign economic indices. An Argentinian author, B. Kliksberg, notes that "instead of looking for more cruel methods of punishing criminals, time has come to look for a new rationalization of the very phenomenon of criminal activity, which at present acquired a much more complex character" [Kliksberg 2006]. A Mexican scientist, M. Moloeznik, speaking about the completely failed "anti-narcotics" 
campaign led by the president F. Calderon together with the US DEA in Mexico, blames the traditional coercive measures as those, which caused a new, powerful wave of violence and assassinations [Moloeznik 2011].

New approaches to the world realities start to, literally, "impose" themselves. They are becoming the imperatives of the human existence. The problem is: how long it will take to the mankind to rationalize and to implement those imperatives in practice? The first and the most important step, on our point of view, will be the reforming of the whole system of international organizations, including the $\mathrm{UN}$, with a view to strengthen their competences in the struggle against international terrorism, illegal drugs smuggling, organized crime and piracy, nuclear proliferation, slavery, discrimination, climate deterioration, etc. On all such issues the BRICS countries usually mark the "proximity or coincidence of positions" in their common documents. But what can be said about the well-known geographic, cultural, political, religious etc. differences between them?

Sometimes one hears that Brazil, for example, is of a much lesser importance for Russia, then its closest neighbors - China and India. To this one can only respond that the globalization (different, as it is) not only shortens geographic and temporal distances. It also makes the once separated problems shared between the geographically and culturally distant countries. Russia, China and India are, first of all, nuclear powers. Brazil is a state of advanced nuclear technologies, which can produce a nuclear bomb in a short time. But what can come out of that?

Many modern security issues acquire nowadays an unmistakably internal character. This newly puts into the limelight the problem of a re-distribution of natural resources (water, rare metals, oil, gas, bioresources etc). Besides, the new and still unknown global problems may arise pretty soon, precisely in the so called "new geographic spaces": open seas, cosmic space, Arctic and Antarctic. Inevitably one should expect the appearance of new kinds of weapons (climatic, genetic, etc.), of new criminal and smuggling (human organs, critical information) practices, etc. If the international law becomes a flexible "instrument" in the hands of those, who, according to the patterns of their legal culture treats it as such, then no old international obligations will be binding any more, and no new ones will appear. The rule of force will prevail.

The so called civilizational "West" is far from being homogeneous: it cannot escape cultural and civilizational dichotomies. To "catch up with the world", the US should enrich their "universal values" with the recognition of history, culture and dignity of other peoples [Kissinger 2014] and look for a broader alliances within the new physical and cyber-space reality. On our point of view, the BRICS is still a futuristic project, which will be ripening through the time, when more states or regional structures may formally or informally take part in it. There are many advantages of the world governed by the "Concert of Civilizations" over that, governed by a single power or powers. The most distinctive one, on my point of view, is the common sense.

The world is at war now: a war for the domination over the new - intellectual space. The "Moment of Truth" for the whole BRICS project demands from its members a sober and a more realistic vision of the whole situation. Either BRICS (all of them, or some countries first, others - later), enter a new phase of development, marked by the cognitive efforts to gain intellectual supremacy over destructive (militarist, consumerist, materialist, libertarian, etc.) postures, or its "super-idea" will finally lose its impetus.

\section{References}

Diamond, J.M. (2011). Collapse. How Societies Choose to Fail or Succeed. Viking Press.

Harari, Y.N. (2015). Homo Deus. A Brief History of Tomorrow. London: Penguin Random House.

Katzenstein, P. (Eds.). (2010-2012). Civilization in World Politics. Books 1-3. Routledge.

Kissinger, H. (2014). World Order. Penguin Press.

Kliksberg, B. (2006). Mitos y realidades sobre la criminalidad en America Latina. Buenos Aires.

Martynov, B.F. \& Lavalle, V.-H. (2019). De la Guerra informative hacía una "nueva guerra fria"? Iberoamérica, 1, 26 - 43.

Martynov, B.F. (2019). Chaos Synergy, Geopolitics And Culture Explain History Of International Relations. A Critique of William Wohlforth. MGIMO Review of International Relations, 64 (1), 19—28. DOI: 10.24833/2071-8160-20191-64-19-28.

Mazover, M. (2017). Governar o Mundo. Lisboa: Edições 70. 
Moloeznik, M.-P. (2011). Apuntes criticos sobre las más recientes iniciativas de reformas legislativas de Presidente Felipe Calderon Hinojosa en material de seguridad y modelo policial. Letras Juridicas. Revista electronica de derecho del Centro Universitario de la Ciénega, 12, 1-31. URL: http://letrasjuridicas.cuci.udg.mx/index.php/letrasjuridicas/ article/view/138/136 (accessed: 03.03.2019).

Morris, I. (2014). War: What Is It Good for? London: Profile Books.

O'Neil, J. (2011). The Growth Map: Economic Opportunity in the BRICS and Beyond. London: Portfolio / Penguin.

Sharma, R. (2010). Paises emergentes. Madrid: Aguilar.

Toropchin, G.V. (2017). From Goa to Xiamen. On Some Aspects of Political Cooperation within BRICS. International Organizations Research Journal, 12 (1), 174-188. DOI:10.17323/1996-7845-2017-01-174. (In Russian).

Voronin, E.R. (2013). Transatlantic Links and BRICS: Prospects of Strategic Co-existence. MGIMO Review of International Relations, 2 (29), 33-37. (In Russian).

Received: 02.04.2019

For citations: Martynov, B.F. (2019). The BRICS: Paradigm Shift in Dealing with New Challenges. Essay. Vestnik RUDN. International Relations, 19 (2), 201-206. DOI: 10.22363/2313-0660-2019-19-2-201-206.

\begin{abstract}
About the author: Martynov Boris Feodorovich - PhD, Dr. of Science (Political Sciences), professor, chief of the Department of international relations and foreign policy of Russia, MGIMO University of the Ministry of Foreign Affairs of the Russian Federation (e-mail: bfmartynoff@gmail.com).
\end{abstract}

DOI: $10.22363 / 2313-0660-2019-19-2-201-206$

\title{
БРИКС: смена парадигмы в условиях новых вызовов
} Эссе

\author{
Б.Ф. Мартынов \\ МГИМО (У) МИД России, Москва, Российская Федерация
}

\begin{abstract}
Человечество начало активно использовать относительно новое геополитическое пространство — информационное. Научно-технический прогресс открывает перед ним новые, пока еще не ясные горизонты. Он приносит с собой перемены, последствия которых могут быть как позитивными, так и негативными, в зависимости от того, кто и с какими целями пользуется его плодами. Сегодняшнее состояние мировой политики характеризуется многими как «непредсказуемое» и «хаотичное». Информационные войны и «фейковые» новости приобрели повседневный характер, сплошь и рядом порождая ложные мнения и искаженное видение реальности. Они, как правило, открывают дорогу к еще большему усложнению кризисов и конфликтов. В то же самое время миру не хватает новых идей, с помощью которых можно было бы найти более адекватные ответы на наиболее актуальные глобальные проблемы. Появления таких новых идей, как мы убеждаемся на практике, трудно ожидать от «старых», традиционных акторов мировой политики.

По мнению автора, страны БРИКС, которые представляют собой новые, «восходящие» цивилизации современного мира, могли бы содействовать коллективной выработке таких идей при условии проведения более активной политики в информационном пространстве на принципиально новой концептуальной основе. Эти страны не связаны путами «Евроатлантической солидарности» и не исповедуют нормы «политкорректности». Основой их новых подходов могло бы стать общее уважение к международному праву, восходящее к специфике их политико-правовых культур, исторических и социальных практик.
\end{abstract}

Ключевые слова: геополитика, глобальные проблемы, информационное пространство, глобальная безопасность, информационная безопасность, БРИКС, мировые цивилизации, «многоцивилизационный» подход, международное право, политическая и правовая культура

\section{Библиографический список}

Воронин Е.Р. Трансатлантизм и БРИКС: перспективы стратегического сосуществования // Вестник МГИМО-Университета. 2013. № 2 (29). С. 33-37.

Мартынов Б.Ф. История международных отношений объясняется синергией хаоса, геополитикой и культурой. К дискуссии с У. Уолфортом // Вестник МГИМО-Университета. 2019. № 1 (64). С. 19—28. DOI: 10.24833/20718160-2019-1-64-19-28. 
Торопчин Г.В. От Гоа до Сямэня. О некоторых аспектах политического сотрудничества в рамках БРИКС // Вестник международных организаций. 2017. Т. 12. № 1. С. 174-188. DOI:10.17323/1996-7845-2017-01-174.

Civilization in World Politics / Ed. by P. Katzenstein. Books 1-3. Routledge, 2010-2012.

Diamond J.M. Collapse. How Societies Choose to Fail or Succeed. Viking Press, 2011.

Harari Y.N. Homo Deus. A Brief History of Tomorrow. London: Penguin Random House, 2015.

Kissinger H. World Order. Penguin Press, 2014.

Kliksberg B. Mitos y realidades sobre la criminalidad en America Latina. Buenos Aires, 2006.

Martynov B.F., Lavalle V.-H. De la Guerra informative hacía una "nueva guerra fria"? // Iberoamérica. 2019. 1. P. 26 - 43.

Mazover M. Governar o Mundo. Lisboa: Edições 70, 2017.

Moloeznik M.-P. Apuntes criticos sobre las más recientes iniciativas de reformas legislativas de Presidente Felipe Calderon Hinojosa en material de seguridad y modelo policial // Letras Juridicas. Revista electronica de derecho del Centro Universitario de la Ciénega. 2011. No. 12. P. 1-31. URL: http://letrasjuridicas.cuci.udg.mx/index.php/letrasjuridicas/ article/view/138/136 (accessed: 03.03.2019).

Morris I. War: What Is It Good for? London: Profile Books, 2014.

O'Neil J. The Growth Map: Economic Opportunity in the BRICS and Beyond. London: Portfolio / Penguin, 2011.

Sharma R. Paises emergentes. Madrid: Aguilar, 2010.

Дата поступления статьи: 02.04.2019

Для цитирования: Martynov B.F. The BRICS: Paradigm Shift in Dealing with New Challenges. Essay // Bectник Pocсийского университета дружбы народов. Серия: Международные отношения. 2019. Т. 19. № 2. C. 201-206. DOI: 10.22363/2313-0660-2019-19-2-201-206.

Сведения об авторе: Мартынов Борис Федорович — доктор политических наук, профессор, заведующий кафедрой международных отношений и внешней политики России МГИМО (У) МИД России (e-mail: bfmartynoff@gmail.com).

(C) Martynov B.F., 2019 